\title{
A subversão do tempo e o espaço configurado em Juan Rulfo e Guimarães Rosa - Páramo, Luvina e El hombre ou, 'aonde nos levou o sonho'?
}

\author{
Cláudia Lorena Fonseca ${ }^{1}$ \\ Centro de Letras e Comunicação /Programa de Pós-graduação em Letras, \\ Universidade Federal de Pelotas-UFPel, Pelotas, RS, Brasil
}

Resumo: A obra de Guimarães Rosa guarda muitos pontos de contato com a de Juan Rulfo, tanto no que diz respeito a seus aspectos temáticos, quanto aos formais. Dentre estes últimos, muito estudados, chamam especialmente a atenção aqueles relacionados ao espaço, o qual, na obra dos autores, não pode ser pensado fora de sua relação com o tempo, que, em diferentes níveis, altera o espaço, pela forma como estes o manipulam, a partir de jogos com a linguagem, constituindo-se em coeficiente de ineditismo e originalidade em sua obra, ao possibilitar que se configurem realidades outras. Neste estudo, aproximamos o brasileiro e o mexicano, portanto, a partir dessa hipótese. Para tanto, nos valemos dos resultados da investigação empreendida por autores tais como Mikhail Bakhtin e Paul Ricoeur, além dos pressupostos de Tiphaine Samoyault, para pensar o diálogo intertextual entre Rosa e Rulfo, a partir da análise dos contos "Páramo", "El hombre" e "Luvina".

Palavras-chave: Guimarães Rosa; Juan Rulfo; Tempo; Linguagem; Intertextualidade.

Title: The subversion of time and the space configured in Juan Rulfo and Guimarães Rosa - Páramo, Luvina and El hombre or, 'where did the dream take us'?

Abstract: Guimarães Rosa's work holds many points of contact with that of Juan Rulfo, both regarding its thematic and formal aspects. Among the latter, much studied, those related to space are particularly noteworthy. However, this category, in the authors' work, cannot be thought outside of its relationship with time, which, at different levels, alters space, by the way they manipulate it, based on games with language, constituting the coefficient of originality in his work, by allowing other realities to be configured. In this study, we approach the Brazilian and the Mexican, therefore, based on this hypothesis. For this, we use the studies of authors such as Mikhail Bakhtin and Paul Ricoeur, in addition to the assumptions of Tiphaine Samoyault to think of the intertextual dialogue between Rosa and Rulfo, from the analysis of the short-stories "Páramo", "El hombre" and "Luvina".

Keywords: Guimarães Rosa; Juan Rulfo; Time; Language; Intertextuality.

\footnotetext{
${ }^{1}$ Doutora em Literatura Comparada pela Universidade Federal do Rio Grande do Sul-UFRGS. Pósdoutorado na Universidad Nacional de Cuyo-UNCuyo-Mendoza, Argentina. Professora Adjunta na Universidade Federal de Pelotas-UFPel, Pelotas. Orcid: https://orcid.org/0000-0003-4787-0575 E-mail: fonseca.claudialorena@gmail.com
} 


\section{Introdução}

Considerando-se a literatura produzida na América Latina no último século e pensando nas relações que podemos estabelecer entre autores da América hispânica e a de língua portuguesa, é lícito afirmar que são muitos os aspectos que nos aproximam, quais sejam: um diálogo entre tradições e sistemas, além de, sobretudo, um diálogo entre autores e obras: não faltam nomes significativos em nossa literatura. Dentre esses, destacamos para este estudo João Guimarães Rosa, brasileiro, e Juan Rulfo, mexicano, os quais compartilham bem mais que um contexto latino-americano de época, marcado por importantes movimentos e transformações no âmbito político-social, com forte repercussão nas diversas áreas do conhecimento, como não poderia deixar de ser. A obra desses autores guarda inúmeros pontos de contato, no que concerne aos seus aspectos temáticos e formais, fazendo com que os temas, relacionados ao universo da região à qual cada um deles está vinculado, transcendam a condição limitadora de um regionalismo nos moldes do que até então se produzia ou, um transregionalismo, na concepção de Antonio Candido, em "Literatura e subdesenvolvimento" (1987). O próprio Candido cita os dois autores com os quais trabalhamos como exemplares dessa forma de pensar e escrever/representar a região.

No entanto, o espaço, em Rulfo e Rosa, não pode ser pensado fora de sua relação com o tempo. Em sua obra, em diferentes níveis, o espaço é alterado pela forma como manipulam essa categoria, seja pela configuração de um tempo ancestral ou mítico, pela concomitância ou sobreposição dos tempos ou, o tempo além do tempo. Mesmo que em alguns casos seja o espaço que chame a atenção em um primeiro momento, por esse aspecto estar à superfície, mais visível e aberto a uma leitura linear, não é o espaço, mas o tempo, o fator de maior relevância para a produção de sentidos. O tempo alterado é que possibilita que se adentre em um espaço somente possível por conta dessa estratégia ou subversão.

Buscamos aproximar Guimarães Rosa e Juan Rulfo, então, a partir de aspectos relacionados à constituição de tempo e espaço, engendrados pela linguagem, sobretudo o tempo, pois julgamos que essa categoria é responsável pelo coeficiente de ineditismo e originalidade em sua obra, ao possibilitar que se configurem realidades outras, paralelas. Para fins de análise, selecionamos da obra dos autores os contos "El Hombre" e "Luvina", de Rulfo, e "Páramo", de Rosa, e não os seus romances, já bastante estudados, primeiro porque pensamos que o conto nos permite observar melhor esses aspectos, por se tratar de um instantâneo da realidade dos fatos narrados, o que favorece o que chamaríamos de livre trânsito entre tempos, considerando-se que não há nessa forma narrativa um conhecimento prévio e/ou posterior aos acontecimentos. Em segundo lugar, porque essas obras estabelecem entre elas uma relação singular, síntese do diálogo permanente que se conformou entre o brasileiro e o mexicano. Situamos "Páramo" como uma espécie de síntese entre os dois contos de Rulfo, como pretendemos evidenciar, além de destacar o intertexto presente nas obras. 
Amparam nossa abordagem os estudos e reflexões de teóricos como Mikhail Bakhtin, no que concerne às questões relativas ao dialogismo, à polifonia e ao discurso citado; e Paul Ricouer, em Tempo e narrativa II, além de Tiphaine Samoyault, cuja concepção de intertextualidade - como memória da literatura; e proposta para o estudo da intertextualidade - uma poética dos textos em movimento, nos interessam especialmente. Segundo a autora, "em vez de obedecer a um sistema codificado muito estrito, a intertextualidade busca mais, hoje, mostrar fenômenos de rede, de correspondência, de conexão, e fazer dele um dos principais mecanismos da comunicação literária. (SAMOYAULT. 2008, p. 42). Para Bakhtin (2002a), a relação estabelecida entre os discursos, no diálogo, é uma relação ativa, não um diálogo no sentido convencional do termo, é evidente, mas discursos que dialogam entre si no interior de uma mesma enunciação. O discurso citado, e suas possibilidades narrativas, são também objeto de investigação do autor, e nos interessa destacá-los. Para Ricoeur, "o tempo do romance pode romper com o tempo real: é a própria lei de entrada na ficção. Mas ele não pode deixar de configurá-lo segundo novas normas de organização temporal que sejam ainda percebidas pelo leitor como temporais, graças às novas expectativas relativas ao tempo da ficção [...]. (1995, p.41). Segundo ele, ainda,

\begin{abstract}
Acreditar que se terminou com o tempo da ficção, porque se perturbou, desarticulou, inverteu, interpenetrou, reduplicou as modalidades temporais às quais os paradigmas do romance 'convencional' nos familiarizaram, é acreditar que o único tempo concebível seja precisamente o tempo cronológico. É duvidar dos recursos de que a ficção dispõe para inventar as suas próprias medidas temporais, e duvidar que esses recursos possam encontrar no leitor expectativas referentes ao tempo, infinitamente mais sutis que as relacionadas à sucessão retilínea". (RICOEUR, 1995, p.41-42)
\end{abstract}

Nosso foco neste estudo é, portanto, sem desconsiderar os temas, o tempo na narrativa na obra dos dois autores que elegemos, privilegiando o diálogo que estabelecem entre eles em sua obra. $O$ tempo a partir de uma abordagem que tem o discurso/linguagem como norte: o discurso/voz que configura o tempo e o espaço.

\title{
El hombre: allá atrás su propia voz
}

Publicado em 1953, na coletânea El llano em llamas, "El hombre" é um dos mais complexos e dos mais estudados contos de Rulfo. Apresenta enredo relativamente simples: é uma história de vingança. Um homem tem o irmão morto e busca vingá-lo; por sua vez o assassino, vítima dessa vingança, vai também em busca de vingança. Sobre sua estrutura, esta se apresenta complexa, sobretudo se consideramos o estatuto do narrador, causa maior de controvérsias entre os investigadores: não há, provavelmente, um único estudo que coincida em relação a esse aspecto. Das muitas análises que encontramos, divergem todas, o que além de raro é instigante. Também a categoria tempo provoca estranhamento, 
intimamente relacionada que está à do narrador. Dessa relação se estabelecem jogos, que determinam, ou indeterminam, no caso, a situação de discurso e, consequentemente os sentidos, possibilitados pelo desdobramento da enunciação e do enunciado. Nesse deslocamento da atenção do enunciado narrativo para a enunciação, "os traços puramente fictícios do tempo narrativo adquirem um relevo distinto" (RICOEUR, 1995, p.110).

No que diz respeito ao conto de Rulfo, podemos dizer que essas possibilidades são levadas ao limite, no jogo produtivo entre ponto de vista e voz narrativa. Para Ricouer, a noção de experiência fictícia do tempo, não poderá evitar esses conceitos "na medida em que o ponto de vista é o ponto de vista sobre a esfera da experiência à qual pertence o personagem e em que a voz narrativa é aquela que, dirigindo-se ao leitor, apresenta-lhe o mundo contado" (1995, p. 147). Como incorporar essas noções ao problema da composição narrativa? Vinculando as categorias de narrador e de personagem. Destacando os estudos de Boris Uspensky, em particular as reflexões relativas aos planos espacial e temporal da expressão do ponto de vista e, ainda, ao plano dos tempos verbais e dos aspectos, Ricouer se propõe a definir e a distinguir entre si esses aspectos. O ponto de vista, para ele, "é de interesse para a composição da obra e torna-se, com Uspensky, o objeto de uma poética da composição" (p.155), a partir do momento em que, adotando pontos de vista variáveis, proporcionam ao autor, multiplicá-los e incorporar suas combinações à configuração da obra". (p.155)

Ponto de vista e voz são noções solidárias e indiscerníveis, muitas vezes. De acordo com Ricoeur (1995), trata-se de uma única função, considerada sob o ângulo de duas questões diferentes: "o ponto de vista responde à questão: De onde se percebe o que é mostrado pelo fato de ser contado? Portanto: de onde se fala? A voz responde à questão: Quem está falando aqui?" (p. 162). A partir de então, subsistiria uma única diferença entre ambos: "[...] o ponto de vista pertence ainda a um problema de composição [...], portanto, permanece ainda no campo de investigação da configuração narrativa; a voz, em compensação, já pertence aos problemas de comunicação, na medida em que se dirige a um leitor", situando-se, assim, "no ponto de transição entre configuração e refiguração", considerando-se que a leitura indica a interseção entre o mundo do texto e o mundo do leitor. (p. 163)

Nesse sentido, o que podemos dizer é que, de acordo com nossa leitura, em "El hombre" é inegável que são várias as vozes narrativas, e nisso estão quase todos de acordo. Entre as vozes que se fazem ouvir no conto estão a do perseguidor, a do homem que é perseguido e a do borregueiro. Além das três vozes, a maior parte dos estudos destaca uma quarta voz, que seria a de um narrador observador/onisciente que conduz a narrativa, dando eventualmente direito à voz, mais ou menos mediada, a cada uma das três personagens que atuam efetivamente nela. Tratar-se-ia, no caso, de um narrador onisciente seletivo, considerando-se a tipologia de Norman Friedman (2002) para essa categoria. Acontece que o tratamento dado ao discurso, no conto, cria situações que dificultam a identificação dessas vozes, a saber: o uso do discurso indireto livre - que Ricoeur (1995) chama de monólogo 
narrativizado, que consistiria em não mais citar o monólogo, mas em contá-lo-, com utilização de recursos gráficos que têm por finalidade identificar essas vozes, o que acaba por contrariar a maioria dos estudos, se bem observado.

Segundo o que constatamos, identifica-se em "El hombre", como primeira voz narrativa, um narrador que a princípio se configuraria como um narrador observador, posto que se apresenta como onisciente e detentor do comando das vozes narrativas. No entanto, chama a atenção o fato de que essa onisciência, em determinados momentos, parece limitada. O tempo se verifica, a princípio, como um passado presentificado: o presente da ação sendo narrado conforme estas se sucedem.

LOS PIES DEL hombre se hundieron en la arena dejando una huella sin forma, como si fuera la pezuña de algún animal. Treparon sobre las piedras, engarruñándose al sentir la inclinación de la subida; luego caminaron hacia arriba, buscando el horizonte. (p.22)

Porém, algo contraria a lógica, o que em Rulfo não surpreende, pelo contrário, convida ao jogo: se estamos diante da perseguição de um homem ao assassino de sua família, como se explica o fato de que o perseguidor segue seus passos para vingar mortes que ainda não ocorrerem? E como se explica, também, que a utilização dos recursos gráficos não segue uma norma na totalidade do texto? Ou seja, sinais que identificam o perseguidorUrquidi, vão se modificando no transcurso da narrativa, como se o narrador entregasse o comando finalmente a essa personagem, o que não ocorre em relação ao perseguidoAlcancia, o qual tem sua voz identificada pelo uso de aspas que abrem e fecham o seu enunciado a cada manifestação desta. Além disso, as manifestações de voz de Alcancia se apresentam em itálico.

"No el mío sino el de él", dijo. Y volvió la cabeza para ver quién había hablado.[...]

"Voy a lo que voy", volvió a decir. Y supo que era él el que hablaba. (p.22)

Situação distinta à de Urquidi, que tem sua voz identificada pelo recurso apenas às aspas, que a princípio abrem e fecham cada manifestação de sua voz, para, em um segundo momento, apenas abrirem essas manifestações, terminando por se apresentarem sem o uso de nenhum desses recursos, em uma variedade considerável de formas de citação do discurso.

"Pies planos - dijo el que lo seguía-. Y un dedo de menos. Le falta el dedo gordo en el pie izquierdo. No abundan fulanos con estas señas. Así que será fácil." (p.22)

Em seu estudo sobre as formas da enunciação nas construções sintáticas, Bakhtin (2002a), a partir de minucioso trabalho, sistematiza, uma tipologia e definições para a análise da enunciação, colocando como fundamento do seu método o discurso citado ou o "discurso no discurso". O discurso citado na narrativa, as outras vozes que emergem do 
discurso do narrador, têm sua ocorrência possível pela utilização do discurso indireto livre, e emergem do indireto livre tanto em voz direta, entre aspas e itálico, entre aspas apenas, ou mediadas pela voz do narrador. Nesse sentido, a investigação de Mikhail Bakhtin é pioneira. E nos orienta na leitura que fazemos.

Nesse sentido, podemos dizer que o narrador, nesta primeira parte do conto, se apresenta em duas vozes em dois tempos distintos, o que causa estranhamento e indeterminação, com a atribuição de voz a um narrador externo. Urquidi narra a princípio exterior aos eventos, considerado o fato de que já está morto, pois cremos que o terceiro familiar morto é ele mesmo, o que o faz dele, nesse caso, um simulacro de narrador observador. No presente da ação sua voz é mediada por esse narrador-simulacro. Conforme a narrativa se aproxima do presente, ele abandona as aspas e cede a voz a si próprio, que a partir de então vai assumir a voz narrativa na qualidade de narrador protagonista, embora siga argumentando/dialogando consigo, posto que todo monólogo se constitui, de fato, em diálogo - princípio do dialogismo bakhtiniano, aqui reforçado pelo caráter de sobreposição dos tempos.

\footnotetext{
¿Por qué habría dicho aquello? Ahora su hijo se estaría burlando de él. O tal vez no. "Tal vez esté lleno de rencor conmigo por haberlo dejado solo en nuestra última hora". Porque era también la mía; era únicamente la mía. Él vino por mí. No los buscaba a ustedes, simplemente era yo el final de su viaje [...] (p.25)
}

Seu interlocutor é Alcancia, com o qual conversa por todo o trajeto de subida e descida, de imersão em outro tempo, o da possibilidade de vingança. Apenas na segunda parte do conto, quando ambos estão mortos, quando já não poderia narrar e cumprido que estava seu propósito, mesmo que por vias tortas, pelas mãos do borregueiro, considerandose que um morto não pode matar ou fazer uso de armas, Urquidi já não tem voz. Poderíamos citar outros indícios nas tramas do texto, como por exemplo, o fato de que essa primeira voz se configura como uma voz local, e a polêmica, que nesse caso não é velada, mas clara, que se evidencia entre as vozes, a qual reproduz a tensão que subjaz ao texto, e que se estrutura em função da morte e da vingança.

Portanto, baseados nos indícios que nos fornece o texto, nos sentimos autorizados a afirmar que, em um dos tempos que se apresentam na primeira parte, Alcancia está vivo e Urquidi morto. No entanto, no tempo que se configura ao final, e que se sobrepõe ao tempo da primeira parte, ambos estão mortos, o que explicaria os momentos, nos primeiros momentos da narrativa, em que se escuta falar, com sua voz que the chega sem que pronuncie palavra e a qual se 'acostuma' a ouvir, já sabendo que Ihe pertence. Urquidi também, em determinado momento afirma que sua voz lhe chega como se viesse de outra parte. O tempo da ação é um tempo presentificado, não é passado, mas outro tempo o qual se sobrepõe ao da narração. As supostas idas de Urquidi 'ao futuro' não deixam claro se está planejando sua vingança ou antecipando o futuro: 
“Lo señaló su propio coraje - dijo el perseguidor-. Él ha dicho quién es, ahora sólo falta saber dónde está. Terminaré de subir por donde subió, después bajaré por donde bajó, rastreándolo hasta cansarlo. Y donde yo me detenga, allí estará. Se arrodillará y me pedirá perdón. Y yo le dejaré ir un balazo en la nuca... Eso sucederá cuando yo te encuentre." (p.23)

Porém, considerando nossa hipótese como válida, poderíamos dizer que se trata de um planejamento: de como ele planejou fazer, e de como ele teria feito, caso pudesse, ou caso não o tivesse feito o borregueiro, o qual, supomos, é quem de fato mata Alcancia, o que se constitui em uma solução narrativa. Como a voz passa ao borregueiro, se instaura a ambiguidade a esse respeito. Foram três os mortos por Alcancia, e em nenhum momento esse terceiro morto é nomeado, além disso, sabemos que estava escuro no momento das mortes, fato que fez com todos fossem assassinados, o que não permite que se possa ter como certa a morte de Urquidi.

"No debí matarlos a todos; me hubiera conformado con el que tenía que matar;
pero estaba oscuro y los bultos eran iguales...[...]" (p.25)

Mas, sabemos também, que na segunda parte do conto, o borregueiro é informado das mortes e se dirige ao delegado, no intuito de confirmar suas palavras.

¿Dice usted que mató a toditita la familia de los Urquidi? De haberlo sabido lo atajo a puros leñazos (p.27)

Ou seja, Alcancia mata 'a Toditita la família de los Urquidi', e não a 'toditita la familia del Urquidi. O que parece deixar claro que sim, Urquidi foi morto. O velório do recém-nascido ocorre provavelmente sem a presença do pai, pelo menos não naquele tempo, mas nesse outro tempo posterior, em que leva suas flores, incompreensivelmente marchitas, para reverenciar o filho morto, de quem não guarda recuerdo, fato que ele só vai compreender posteriormente. Nesse outro tempo, o da perseguição, Urquidi se referiria a ele mesmo no momento da morte como 'él'.

\footnotetext{
“Hijo - dijo el que estaba sentado esperando-: no tiene caso que te diga que el que te mató está muerto desde ahora". ¿Acaso yo ganaré algo con eso? La cosa es que yo no estuve contigo. ¿De qué sirve explicar nada? No estaba contigo. Eso es todo. Ni con ella. Ni con él. (pp.25-26)
}

Ainda com relação ao borregueiro, que conversa com o senhor doutor, certamente a autoridade encarregada do caso, seu interlocutor mudo com voz mediada por ele próprio, caracterizado como narrador testemunha, podemos afirmar que seu discurso não é confiável, além disso são perceptíveis características de sua personalidade que o identificam como sujeito igualmente violento, bem como ardiloso: 
Me gusta matar matones, créame usted. No es la costumbre; pero se ha de sentir sabroso ayudarle a Dios a acabar con esos hijos del mal. (p.27)

Somado a esses aspectos, é evidente que o tempo que compartilhou com o perseguido é de tensão, claramente o borregueiro não é simpático à figura de Alcancia. Distingue-se, também, uma polêmica velada na interação entre eles, mesmo que o que narra quase não transcreva suas próprias réplicas no diálogo estabelecido com o homem. Nesse caso, trata-se de polêmica velada, no que diz respeito ao discurso do narrador que cita o do fugitivo. "A palavra do outro permanece fora dos limites do discurso do autor, mas este discurso a leva em conta e a ela se refere" (BAKHTIN, 2002b, pp.195-196), agindo, influindo e, de certa forma, em maior ou menos grau, determinando a palavra do autor, embora permaneça fora desta. No que diz respeito ao discurso do borregueiro em relação ao senhor doutor há uma polêmica interna. E a voz de Alcancia agora tem aspas, mas não itálicos, pois está morto e sua fala é mediada pelo narrador, seu discurso direto emerge do indireto do borregueiro.

De haberlo sabido se habría quedado en juicio y con la boca abierta mientras estaba bebiéndose la leche de mis borregas [...] (p.27)

Pero dice usted que acabó con la vida de esa gente. De haberlo sabido. Lo que es ser ignorante y confiado. Yo no soy más que borreguero y de ahí en más no se nada. ¡Con decirles que se comía mis mismas tortillas y que las embarraba en mi mismo plato! (p.28)

Além disso, seria óbvio que as autoridades fossem em busca de Urquidi, pela morte de Alcancia, e não ao borregueiro, como o fazem. Outros detalhes chamam a atenção também, como por exemplo, a afirmação de que Alcancia não tinha um machado no momento em que passa pela primeira vez, quando sabemos que ele tinha, embora pudesse tê-lo conseguido do outro lado, antes do assassinato. Pela ênfase que o narrador dá ao fato, nos parece que o tenha tomado ao outro, além de este se configurar como o motivo mais plausível para que não tenha reagido às afrontas do fugitivo. E mais, seria improvável que o borregueiro não visse também a Urquidi, sentado à beira do rio, sendo que ao outro homem ele viu em todas suas idas e vindas.

Lo vi venir más flaco que el día antes con los huesos afuerita del pellejo, con la camisa rasgada. No creí que fuera él, así estaba de desconocido. [...] Le vi los ojos, que eran dos agujeros oscuros como de cueva. (p.27)

Podemos dizer que são muitas as evidencias semeadas ao longo do texto, mais ou menos camufladas, o que por fim faz com que levantemos nossas próprias hipóteses, sem que seja possível comprovar em definitivo nenhuma delas, pois não há a possibilidade de certeza com Rulfo. Os recursos e estratégias utilizados pelo autor em "El hombre" se 
radicalizam em "Luvina", como iremos observar, e se exacerbam em Pedro Páramo.

\title{
Luvina: ¿Qué país éste, Agripina?
}

No que diz respeito a "Luvina", conto igualmente publicado em El llano en llamas (1953), podemos dizer que, considerando a situação que se apresenta quanto à produção de sentidos, só podemos falar em uma das leituras que se pode fazer, ou um dos possíveis sentidos. Ninguém se arrisca a dizer que está convicto em relação à sua leitura da obra. Nesse conto, também de enredo simples, encontramos uma situação aparentemente banal: um homem se dirige a um lugar situado no alto de um cerro. Antes de subir, para em um bar e escuta o que tem a contar alguém que já havia estado lá. Este dá conta de sua experiência, no intuito de orientar aquele que para lá segue. Assim como em "El hombre", em "Luvina" os jogos com o tempo se destacam e determinam seus rumos e a ambiguidade que constitui a obra que, por sua vez, determina as múltiplas leituras que se fazem. Trata-se de uma narrativa sobre o tempo, e suas possibilidades. Polifônica, "convida-nos mais a dissociar o princípio de tecer da intriga do princípio monológico e a estendê-lo até o ponto em que a ficção narrativa se transforma em um gênero inédito." (RICOEUR, 1995, p.161). O que nos remete mais uma vez a Bakhtin, que sistematiza a noção a partir do estudo sobre a obra de Dostoievski, estabelecendo as bases do que se chamaria romance polifônico, estrutura romanesca responsável pela ruptura com o princípio que o autor chama monológico. Segundo Ricouer, a estranha originalidade dessa modalidade "é feita, portanto, de uma revolução na concepção do narrador e da voz do narrador, tanto quanto na do personagem" (1995, p. 159).

\begin{abstract}
A relação dialogal entre os personagens é, de fato, desenvolvida a ponto de incluir a relação entre o narrador e seus personagens. Desaparece a consciência autoral única. Em seu lugar, sobrevém um narrador que conversa com seus personagens e se torna ele próprio uma pluralidade de centros de consciência irredutíveis a um denominador comum. É essa 'dialogização' da própria voz do narrador que faz a diferença entre romance monológico e romance dialógico. É, portanto, a própria relação entre discurso do narrador e discurso do personagem que é inteiramente subvertida." (RICOEUR, 1995, p.159)
\end{abstract}

Essa relação entre os discursos de narrador e personagens é radicalizada por Rulfo em "Luvina". O discurso do narrador é o da personagem desdobrada - narrador desdobrado temporalmente, que se mistura a outras vozes. Ricoeur tem como especialmente cara a ele, em suas reflexões sobre tempo e narrativa, a noção de voz, por suas importantes conotações temporais, pois, "como autor de discurso, o narrador determina, de fato, um presente - o presente da narração -, tão fictício quanto a instância de discurso constitutiva da enunciação narrativa." (1995, p.161). São muitos os jogos que envolvem a noção de espaço e tempo neste conto do autor mexicano, que identificamos em suas estratégias de composição, suas opções e na construção do texto como um todo. Só personagens secundários têm nome na 
obra, o que impede que saibamos quem narra e quem vive de fato os acontecimentos, ou que possamos distingui-los. Espectrais todos eles, "Luvina", antecipando Comala. Além desse aspecto, observamos também um jogo com os advérbios de lugar: Allí/allá; e com os tempos verbais: Esteve/está/estará, ao ritmo do vento que sopra sem cessar, remexendo tudo, fora e dentro, determinando o caráter de seus habitantes.

-Ya mirará usted ese viento que sopla sobre Luvina. [...] Ya lo verá usted. Se planta en Luvina prendiéndose de las cosas como si las mordiera. [...] uno lo oye mañana y tarde, hora tras hora, sin descanso, raspando las paredes, [...] hasta sentirlo bullir dentro de uno como si se pusiera a remover los goznes de nuestros mismos huesos. Ya lo verá usted. (p.60)

A narrativa se apresenta no presente com um narrador, em primeira pessoa, que conta a experiência que viveu. Portanto, o narrador é alguém que "esteve lá" (BENJAMIN, 1994), de alguma forma. Faz isso a partir da voz de um - suposto - outro narrador, com a qual mistura sua própria voz e experiência, em um passado presentificado. O interlocutor (ou interlocutores) nesse momento não se define $(m)$. São dois, a princípio, os personagens que atuam, e não importa que um deles não se pronuncie em voz narrativa naquele espaço/tempo, embora possamos verificar ali a presença de um interlocutor interno à diegese. Podemos supor, inclusive, outro personagem que não se manifesta em voz, este, em momento algum.

Em um primeiro momento, poderíamos pensar este narrador como testemunha, considerando que narra no presente uma ação passada, da qual fez parte, protagonizada por alguém do local que conta a sua própria experiência em Luvina, em um passado anterior ao presente da ação. Essa primeira voz narrativa em primeira pessoa seria a do homem que estava prestes a subir a Luvina no presente da ação, quando aparece como interlocutor mudo. No entanto, as diversas leituras que se fazem divergem a esse respeito, como costuma ocorrer com a leitura crítica da obra de Rulfo. Alguns autores afirmam que essa primeira voz narrativa no presente é a do homem que narra no presente da ação (el hombre aquel que habla) a um interlocutor mudo; por sua vez, outros afirmam que é a voz do interlocutor mudo do passado, depois de sua volta, e de ter constatado a veracidade da informação que recebeu antes de subir, contando o fato a uma outra pessoa que talvez vá também subir. Pensamos que algumas leituras simplificam muito, pois buscam uma linearidade que não existe na obra do mexicano. Seria ignorar as questões relativas ao tempo na obra rulfiana. 0 que pensamos a respeito dessas duas possibilidades é que, a primeira delas é muito simplista; a segunda é mais viável, no entanto, desconsidera outros fatores, como, sobretudo: de quem é a experiência contada na cantina? $E$, quem conta a experiência na cantina?

Tendo em vista as possibilidades que se apresentam, diríamos que nos inclinamos mais para uma leitura que privilegia a situação de tempos que se sobrepõem, embora considere duas vozes narrativas: a de um narrador que introduz o relato, no presente, 
contando a experiência que viveu a um interlocutor mudo (com o qual nos identificamos), a princípio com certa objetividade, simulando, ou desejando simular, certo distanciamento dos fatos, o que faria pensar um narrador observador ou testemunha, ou, no limite, um narrador que viveu a experiência e agora, distanciado, adquiriu sabedoria para narrar; e um segundo narrador (se é que se pode chamar assim), personagem, no passado intermediário, que fala em voz direta com o primeiro narrador, antes que este subisse à Luvina, antes da experiência que está sendo contada, objetiva e subjetivamente, no presente.

No entanto, no decorrer da narrativa no passado, esse primeiro narrador também narra, com sua voz misturada à do narrador do passado intermediário, que por sua vez conta a um interlocutor mudo sua experiência. Esse primeiro narrador seria o interlocutor mudo do presente da ação (passado intermediário), que opta por se 'auto-emudecer', substituindo suas réplicas no diálogo por reflexões pós-experiência, pois essas réplicas se constituem em intervenções de um sujeito sem conhecimento do que viria, e a ele não interessa rememorar esses apartes, portanto, não há por que colocar-se na cena em voz direta. Nesse contar, por vezes divaga, adentra o outro tempo, o de Luvina, pelas primeiras reticências, dando voz, então, ao narrador do passado intermediário, o sujeito 'local' (el hombre aquel que hablaba).

...Y la tierra es empinada. Se desgaja por todos lados en barrancas hondas, de un fondo que se pierde de tan lejano. Dicen los de Luvina que de aquellas barrancas suben los sueños [...]. (p.60)

A experiência tem vozes confundidas e, pelas indicações gráficas, é possível distinguilas vagamente, estando estas entre o contar e a rememoração. Observamos que as formas de emergência do discurso direto do interior do indireto livre resistem mesmo à tão detalhada tipologia de Bakhtin, embora não se discuta o dialogismo interno. Apenas não temos certeza sobre quem, de fato, fala.

\footnotetext{
Los gritos de los niños se acercaron hasta meterse dentro de la tienda. Eso hizo que el hombre se levantara, fuera hacia la puerta y les dijera: “iVáyanse más lejos! ¡No interrumpan! Sigan jugando, pero sin armar alboroto." (p.61)

"...Sí, llueve poco. Tan poco o casi nada, [...] como si allí hasta a la tierra le hubieran crecido espinas. Como si así fuera." (p.61)
}

A voz do primeiro narrador parece rememorar enquanto conta e, no meio desta, se apresenta a voz do segundo narrador, como se a voz deste, que conversa com ele no passado, viesse de longe, filtrada, e ficasse diluída na sua rememoração, pela qual se deixa levar, nela afundando. Quando o primeiro narrador começa a divagar, o segundo vai perdendo voz direta. Apenas duas vezes mais esta aparece direta: quando vai adentrar o outro passado mais passado e contar sua história, e quando sai temporariamente dela, para voltar em seguida. Mas neste momento se mesclam as vozes dos dois narradores e suas impressões de Luvina, a ponto de não se distinguirem. Essas meio-entradas e meio-saídas 
daquele espaço aparecem com reticências e uma ou duas aspas, dependendo da posição, mais interior ou exterior a esse espaço.

\footnotetext{
"Nosotros, mi mujer y mis tres hijos, nos quedamos allí, parados en la mitad de la plaza, con todos nuestros ajuares en nuestros brazos. En medio de aquel lugar en donde sólo se oía el viento... (p.63)

“...¿¿No cree que esto se merece otro trago? Aunque sea nomás para que se me quite el mal sabor del recuerdo." (p.65)
}

As experiências se confundem, nos parece, e é sempre a mesma experiência a de Luvina. Aquele que narra desde lá, em algum momento é chamado pelos locais de professor, e ele tem um discurso mais erudito, o que poderia fazer supor que, para lá, de tempos em tempos é enviado alguém a fim de exercer essa função, e que, nesse bar/portal, narra-se eternamente a experiência dilacerante daquele espaço-tempo, onde talvez possamos cogitar que todos estejam mortos, inclusive os narradores. Não se sabe se é possível sair de Luvina.

\footnotetext{
“-Tú nos quieres decir que dejemos Luvina porque, según tú, ya estuvo bueno de aguantar hambres sin necesidad -me dijeron-. Pero si nosotros nos vamos, ¿quién se llevará a nuestros muertos? Ellos viven aquí y no podemos dejarlos solos.

"Y allá siguen. Usted los verá ahora que vaya. Mascando bagazos de mezquite seco y tragándose su propia saliva. Los mirará pasar como sombras, repegados al muro de las casas, casi arrastrados por el viento. (p.65)
}

Nesse sentido, há um detalhe a se considerar: o segundo narrador afirma que Luvina o matou. Que voltou acabado (p.62). Resta saber que tipo de morte é essa. Já o primeiro narrador afirma que fez o experimento e que este se desfez.

En esa época tenía yo mis fuerzas. Estaba cargado de ideas... Usted sabe que a todos nosotros nos infunden ideas. $Y$ uno va con esa plata encima para plasmarla en todas partes. Pero en Luvina no cuajó eso. Hice el experimento y se deshizo... (p.66)

Ao mesmo tempo, a voz que sabemos ser a do hombre aquel que habla, pois está indicado, ao começar a contar sobre a experiência no alto, menciona que trata-se de uma primeira experiência: "le contaba que cuando llegué por primera vez a Luvina [...]" (p.62). Na sequência, identificamos uma voz narrativa que afirma que não havia dito mais nada aos habitantes de Luvina e que de lá saiu e nunca mais voltou. E nem pensa em regressar. Portanto, a princípio, essa voz seria, então, a do primeiro narrador. No entanto, ela se apresenta a partir da abertura de aspas, sem fechá-las, cuja ocorrência normalmente vinculamos ao segundo narrador, o que para nós parece reafirmar o quanto é complexa a tarefa de dissociá-los, e a suas vozes, que é o que talvez alimente as versões quanto a uma única voz narrativa em "Luvina". 
“Ya no volví a decir nada. Me salí de Luvina y no he vuelto ni pienso regresar. (p.66)

Afirma Paul Ricoeur (1995) que a finalidade dos jogos com o tempo é a de articular uma experiência do tempo: "O que chamamos aqui de experiência fictícia do tempo é apenas o aspecto temporal e uma experiência virtual do ser no mundo proposta pelo texto." (p.182). Em Tempo e narrativa II, no capítulo "A experiência temporal fictícia", ao tratar do tempo na ficção, o autor analisa três obras: Mrs Dalloway, de Virginia Woolf; Em busca do tempo perdido, de Marcel Proust e A montanha Mágica, de Thomas Mann, as quais, segundo ele, cada uma a sua maneira, exploram "modalidades inéditas de concordância discordante que já não afetam apenas a composição narrativa, mas a experiência viva dos personagens da narrativa." (p.183). Para designar essas "representações variadas de concordância discordante" (p.183), o autor utiliza o termo variações imaginativas, que seriam "variedades da experiência temporal que apenas a ficção pode explorar e que são oferecidas à leitura com o intuito de refigurar a temporalidade comum," (p. 183). Das três obras que analisa, nos interessa destacar, brevemente, A montanha mágica, que Thomas Mann publica em 1924, pela proximidade de algumas dessas variedades da experiência temporal com a obra de Rulfo.

Em A montanha mágica, o protagonista, Hans Castrop, adentra um tempo e um mundo em que as medidas temporais estão abolidas. Segundo Paul Ricoeur, "um universo no qual o reinado da doença e da morte já está instituído" (1995, p.203), e onde qualquer um que ali adentre se torna um condenado à morte. Essa seria a magia desse lugar fora do tempo e do espaço, acima de qualquer outro aspecto: "o feitiço pela doença e pela pulsão de morte". (p.204). No entanto, mais que tudo, a obra de Mann é uma narrativa que se debruça sobre o tempo. De forma explícita, o protagonista se indaga e reflete sobre o tempo e sobre a possibilidade de apreendê-lo pela narrativa: "Pode narrar-se o tempo, o tempo em si mesmo, como tal e em si?" (p.622), se pergunta. E, ainda: "É o tempo uma função do espaço? Ou vice-versa? Ou são ambos idênticos?" (p.213). Ricoeur observa ainda que, no confronto do protagonista com o tempo abolido, se contrapõem o tempo dos "de cima" - ou, os fora-do-tempo, e o tempo cronológico dos que vivem na planície - os "de baixo", separando dois mundos antagônicos. Essa oposição espacial reforça a oposição temporal.

O mesmo, guardadas as devidas proporções, poderíamos dizer a respeito de "Luvina", inclusive no que diz respeito à construção de espaços que se opõem a partir do alto/baixo. Acreditamos que as questões que se põe a personagem de Thomas Mann são também aquelas às quais se dedica Juan Rulfo em sua obra, em uma resposta a elas. Uma forma de resposta, diríamos, que é a própria exploração das possibilidades que se abrem nessa busca. A experiência do tempo que emerge da linguagem. O certo é que, no conto do autor mexicano, os jogos com o tempo, a partir da linguagem, instituem um espaço, que é um espaço de indefinição, e do insólito, fora do tempo: um espaço além do tempo. 
-Me parece que usted me preguntó cuántos años estuve en Luvina, ¿verdad...? La verdade es que no lo sé. Perdí la noción del tiempo desde que las fiebres me lo enrevesaron; pero debió haber sido una eternidad... Y es que allá el tiempo es muy largo. Nadie lleva la cuenta de las horas ni a nadie le preocupa cómo van amontonándose los años. Los días comienzan y se acaban. (p.65)

Lugares do transtorno, espaços que se constroem pela ocorrência do tempo, agindo sobre o homem, que verbaliza esse espaço e a si mesmo, como sujeito nesse espaço, nesse tempo fora e além do tempo, configurados pela linguagem: o universo da obra de Juan Rulfo. "Onde estamos? Que é isso? Aonde nos levou o sonho?" (MANN, p.823). E talvez muitos dos personagens, no universo do outro autor ao qual nos dedicamos, se perguntem o mesmo.

\section{Páramo: canil de ventos}

Em abril de 1948, Guimarães Rosa, então representante brasileiro na IX Conferência Pan-americana, em Bogotá, vive uma experiência que, pode-se dizer, marcará sua obra a partir de então. Rosa presencia o acontecimento que viria a ser chamado Bogotazo, ou os eventos que se seguiriam ao assassinato de Jorge Eliécer Gaitán, então candidato à presidência da Colômbia. Líder popular, Gaitán representava a possibilidade de mudanças no sentido do combate às desigualdades sociais. Sua morte, nas condições em que ocorreu, desencadeia instantaneamente uma revolta popular, com depredações, mortes - inclusive a de seu suposto assassino, pela multidão, e conflitos que perduraram por duas décadas, pelo menos, com consequências de longo alcance.

A experiência do Bogotazo culmina um período conturbado e traumático na vida de Guimarães Rosa, em que viveu também a Segunda Guerra Mundial na Alemanha nazista, como Vice-cônsul na embaixada brasileira, seguida por um período igualmente traumático, de 1942 a 1944, na mesma Bogotá, logo de seu retorno da Europa. Rosa aparentemente não escreveu ou falou sobre essa experiência, naquele momento e muito tempo depois, pelo menos não há divulgação de relato seu a respeito, no entanto, ainda viva, ela é mencionada em seu discurso de posse na Academia Brasileira de Letras, em 1967, pouco antes de sua morte:

Nem esqueço, em Bogotá, quando a multidão, mó milhares, estourou nas ruas sua alucinação, tanto o medonho esbregue de uma boiada brava. Saqueava-se, incendiava-se, matava-se etc. Três dias, sem policiamento, sem restos de segurança, o Governo mesmo encantoado em palácio. Éramos, bloqueados em vivenda num bairro aristocrático, cinco brasileiros, e penso que nem um revólver (ROSA, 1967).

Não obstante, a menção ao Bogotazo no discurso de posse na Academia não é o único registro dessa experiência, ela está 'registrada' também em uma narrativa singular, considerando-se o conjunto de sua obra. Trata-se de "Páramo", de 1948, narrativa curta, publicada junto a outros inéditos, em Estas estórias, obra póstuma de 1969, organizado por 
sua filha e por seu amigo, o crítico e tradutor Paulo Ronái. Autobiográfico e de ritmo pesado, opressivo, narra uma experiência extrema do ponto de vista psicológico. Sente-se nele, latente, uma grande tensão, que é mais que pessoal, a qual eclodiria nos eventos do Bogotazo.

Pouco conhecido e pouco estudado, até poucos anos, "Páramo" se destaca no corpus rosiano, talvez por se constituir em uma narrativa supostamente inacabada, reunida em uma compilação mais ou menos irregular e póstuma; por se apresentar como um quase-relato; ou porque, diferente das demais obras do autor, não registrar o espaço do sertão, o que provoca o estranhamento. Nele, uma voz narrativa, no presente da narração, introduz os fatos que serão narrados a partir da apresentação do tema e de um argumento, ponto de vista a ser defendido, interpelando seus 'irmãos': “[...] às vezes sucede que morramos, de algum modo, espécie diversa de morte, imperfeita e temporária, no próprio decurso desta vida. [...] Mas o que vem depois é o renascido, um homem mais real e novo [...]. Irmãos, acreditem-me." (ROSA, 1969, p.177). A partir de então, põe-se a contar a história de um homem e o que sucedeu a ele em uma cidade que, pela descrição, identificamos como sendo Bogotá, a qual este chegou degredado, deslocado espacialmente, estrangeiro, evidenciando o caráter não exatamente opcional da situação.

Fato interessante, podemos observar nessa narrativa a trajetória evolutiva do escritor. Mais prolixo nos contos dos primeiros anos de sua produção, identificamos certa irregularidade em "Páramo", com momentos em que este se aproxima ou se distancia do que conhecemos como escritura rosiana. Distinguem-se, por exemplo, menos jogos com as palavras, um número não tão considerável de neologismos e arcaísmos, menor (aparente) ambiguidade. No entanto, a linguagem já é reconhecível, para os que adentraram a obra de Rosa a partir das narrativas posteriores, embora publicadas anteriormente. E é reconhecível justamente e apenas por isso. Guimarães Rosa criando um seu precursor que é ele mesmo. De qualquer forma, na qualidade de texto vinte anos reescrito, em muitos momentos identificamos um Rosa mais próximo daquele do Grande Sertão: veredas ou o de Primeiras estórias.

Quanto às questões que dizem respeito ao tempo, estas se apresentam sobretudo relacionadas ao tema, pela ação, ou eventos ocorridos, o que provavelmente também decorre do fato de que foi escrito ainda na fase inicial da carreira do escritor, final dos anos 40, mais ou menos a mesma época em que escreve Sagarana, quando então a síntese rosiana ainda não havia sido desenvolvida e alcançada.

Lá, no hostil espaço, o ar era extenuado e raro, os sinos marcavam as horas no abismático, como falsas paradas no tempo, para abrir lástimas, e os discordiosos rumores humanos apenas realçavam o grande silêncio, um silêncio também morto, como se mesmo feito da matéria desmedida das montanhas. (ROSA, 1969, p.178)

O ar rarefeito como um não-tempo, possibilidades de tempo, ou de se adentrar um 
outro tempo, é o que se observa. E o vocabulário, que contribui para a configuração desse espaço e tempo, envolto em névoa e neblina. E vento, que antecipa "o diabo na rua, no meio do redemunho" do Bogotazo e do Grande sertão: "Toda esta cidade é um páramo" (p.184). No que diz respeito ao léxico, ainda, percebemos o emprego de palavras e expressões do idioma espanhol, 'aportuguesadas', o que contribui para a ambientação: "São fantasmas, soturnos transeuntes, vultos enxergados através de robustas rexas de ferro das ventanas, moradores dessas casas de balcões salientes sobre as calhes [...]" (p.186). Algo se prepara. Na sequência, a voz narrativa descreve a cidade e tudo nela é morte e premonição da morte que se gesta. No parágrafo seguinte à descrição inicial da chegada ao lugar, essa voz assume a primeira pessoa do singular: "Ah, entre tudo, porém, e inobstante o hálito glacial com que ali me recebi, de começo não pude atinar a ver o transiente rigor do que me aguardava [...] o regresso ao amargo [...] Tanto cheguei..." (p.178)

Em "Páramo", a desestabilização do tempo não se dá via estratégias discursivas ou ambiguidades, não no sentido de vozes discursivas, pelo menos, trata-se de uma experiência de despersonalização, provocada pelo soroche, a princípio, cujos efeitos são reais, exacerbando o sentimento de exilio, a desterritorialização do ser 'que é porque faz parte de um espaço', o seu. Longe desse espaço é como se se desdobrasse, estando ali, 'morto', pois é onde está seu corpo. Ele mesmo está como em outra parte, fora do ser: a morte aquela. Por outro lado, se o mal do soroche é real, as premonições se situam em outro terreno, o da subjetividade. Mas estas seriam de fato premonições ou tudo é efeito do soroche e do que vive? Aqui observamos um elemento característico da obra de Rosa, uma estratégia discursiva, que instaura a ambiguidade, da qual se vale o autor para escapar ao elemento não comprovável, enveredando pelo insólito 'apenas', como em 'Um moço muito branco', de Primeiras estórias, por exemplo, ou em Grande sertão: veredas, em que se apresenta um suposto pacto no qual o diabo não se materializa: tratamento dado às questões do insólito ou do fantástico em sua obra, via discurso ou outras estratégias que impedem que se diga que sim. Por esse motivo não podemos incluir Guimarães Rosa, de fato, entre os autores do que se convencionou chamar de Realismo mágico latino-americano - que por si só já apresenta irregularidade. A esse respeito, podemos dizer ainda que é em "Páramo"' que os vínculos de sua obra com a América latina estão mais evidentes, ironicamente, a partir de uma narrativa paradoxal, de tema não regional, nesse exílio do sertão/casa.

Sobre os elementos ou estratégias utilizados na configuração desse tempo fora do tempo, podemos dizer que aquele que mais se destaca, para além do léxico, e que configura um tempo metafisico, é o recurso aos tempos verbais. Em sua reflexão sobre a relação entre a organização narrativa e os jogos com o tempo, Paul Ricoeur (1995) considera os recursos oferecidos à enunciação pelos tempos do verbo para tratar dos jogos com o tempo resultantes do desdobramento entre enunciação e enunciado (p.112). Segundo o autor, o estudo dos tempos verbais da ficção narrativa, em especial o do monólogo contado "colocou-nos várias vezes no meio de um jogo de interferências entre os tempos do narrador e o dos personagens". (p.161) 
Partindo da distinção introduzida por Benveniste entre história e discurso, e considerando que ao se referir a discurso tem em vista que este designa qualquer enunciação que supõe um locutor e um ouvinte, sendo que, no primeiro, a intenção é influenciar o outro de alguma maneira (1995, p. 112), Ricoeur ressalta o essencial do pensamento de outros teóricos que se dedicaram ao tema e interessam-se mais pelo papel do discurso na própria narrativa do que pela oposição entre discurso e narrativa (p.114). Destaca, nesse sentido, os estudos de Kate Hamburger, afirmando que Ihe devemos "ter ela distinguido claramente a forma gramatical do tempo do verbo, em particular dos tempos passados, de sua significação temporal sob o regime da ficção", ou seja, o corte que a ficção literária introduz no discurso (p.115). Segundo o autor, "é a entrada no discurso de verbos, que designam processos internos cujo sujeito é fictício, que acarreta a reviravolta do sistema dos tempos verbais no regime de ficção." (p.115).

Sobre os estudos de Weinrich, dos quais retém alguns pressupostos, como por exemplo, aqueles que dizem respeito à distribuição dos tempos das línguas naturais em três eixos, quais sejam: a situação de locução (mundo comentado e mundo contado); perspectiva de locução (relação de antecipação, coincidência ou retrospecção entre o tempo do ato e o tempo do texto); dar relevo (que consiste em projetar certos contornos no primeiro plano rejeitando os outros para o plano de fundo) (1995, p.123), e dando ênfase ao eixo da situação de locução e à distinção entre mundo comentado e mundo contado, além das análises do autor dedicadas às transições temporais, Ricoeur afirma que a disposição adotada por Weinrich é particularmente apta a mostrar como a invenção das intrigas se articula sobre a sintaxe dos tempos verbais (1995, pp.125-126), embora não esteja de acordo com sua teoria em sua totalidade. Assim, o autor destaca a afinidade profunda que é possível discernir, segundo ele, entre a teoria dos tempos verbais e teoria da composição narrativa.

Afirma Ricoeur que, "a ficção não apenas conserva o vestígio do mundo prático, do fundo do qual ela se destaca, mas reorienta o olhar para os traços da experiência que 'inventa', isto é, ao mesmo tempo descobre e cria." (1995, p. 130). Em “Páramo", observamos que o jogo que instaura o autor com os tempos verbais é responsável em grande medida pelos jogos com o tempo na narrativa, sua indeterminação e a possibilidade de se pensar a ocorrência de outras formas e medidas de tempo. O discurso fragmentado, a fala entrecortada pelo emprego abundante de sinais de pontuação, como vírgulas e pontos, simulam um discurso 'ofegante' pela situação de pavor e pânico, além da dificuldade de respirar do protagonista da experiência limite. $O$ jogo entre os tempos verbais e advérbios de lugar contribui também com essa percepção de tempo e espaço específicos.

Mas, o frio, que era insofrível. Aqui longínquo, tão só, tão alto, e me é dado sentir os pés frios do mundo. Não sou daqui, meu nome não é o meu, não tenho um amor, não tenho casa. Tenho um corpo? (p.179)

Assustou-me, um tanto, sim, a cidade, antibórea, cuja pobreza no ar exigiria, para respirar-se, uma acostumação hereditária. [...] Esta cidade é uma hipótese imaginária... Nela estarei prisioneiro, longamente, sob as pedras quase irreais e as 
nuvens que ensaiam esculturas efêmeras. (p.179)

Com que assim, agora aqui estou. Aqui, foi como se todo o meu passado, num instante, relance, me aguardasse [...]. A cidade era fria. Aqui, tão alto e tão em abismo, fêz-se-me noite. Cheguei. (p.181)

E vim, o mais atrás, após todos. Como um cachorro. O trecho todo, vou. (p.195) (grifos nossos)

Observa-se a ocorrência de discurso direto emergindo do indireto do narrador, em "Páramo", mas trata-se da mesma voz narrativa, em tempos distintos: o eu que narra é um eu pós-experiência, que dá voz direta ao eu deslocado temporalmente, no passado, um eu presentificado, mas consciente desse fato, e que se sabe 'sobrevivente', apesar da experiência que viveu, sentida como similar à morte. Onisciência seletiva de si, ampliando a tipologia de Norman Friedman. Estar lá e aqui. Dois tempos de fato, desdobrados, e dois tempos no presente dos eventos narrados, ele desdobrado. Porém, quem, de fato, voltou? Pode-se dizer que não é a mesma pessoa, por esse motivo, de certa forma talvez possamos falar também em duas vozes distintas, mas mediadas por esse narrador que introduz a narrativa.

\footnotetext{
A confirmação do meu traspasso [...] Mas ocorre-me, mais que mais, aquele outro estado, que não é de viva vigília, nem de dormir, nem mesmo o de transição comum - mas é como se o meu espírito se soubesse a um tempo em diversos mundos, perpassando-se igualmente em planos entre si apartadíssimos. (p.186)

E tudo parecia para sempre, trans muito, atrás através. (pp.182-183)
}

Poderíamos afirmar que os tempos que se sobrepõem correspondem, pelo menos, aos dois tempos das duas experiências bogotanas: o soroche, 1942, e o Bogotazo, 1948. Ambas aniquiladoras, apresentariam-se amalgamadas em "Páramo". Também o desdobramento do protagonista está associado ao amálgama das duas experiências. Por esse motivo, se explicariam os tempos e as vozes sobrepostos, e esse 'eu' desdobrado em mais dois tempos: o presente e os dois passados que se mesclam e se presentificam, alternadamente, e o jogo com o presente, o passado e o futuro, além do futuro presentificado. A experiência 'real' aludida é a da primeira estancia ali, mas subjaz a da segunda. Não podemos esquecer que é apenas após o segundo evento que o conto foi escrito.

Bogotá: "de lá, da desolação paramuna, vir-me-ia a morte. Não a morte final equestre, ceifeira, ossosa, tão atardalhadora. Mas a outra, aquela." (p.179). 'Aquela' seria a de Gaitán, a qual mata algo nele também? Ou a sua espécie de morte, decorrente da mal do soroche? Ou ambas? O vivido na capital da Colômbia é tão 'intenso' e desestabilizante do humano, e da sua humanidade que, somado à experiência de desumanização da guerra daria origem ao seu único romance: Grande sertão: veredas ou, ao "diabo na rua no meio do redemunho". 
Há sonhos premonitórios. Esta cidade eu já a avistara, já a tinha conhecido, de antigo, distante pesadelo. [...] entre passado e futuro - trevas e névoas - e o mundo, maquinal. (p.179)

A primeira experiência, o 'distante pesadelo', essa espécie de morte, se configuraria como 'sonho premonitório' da segunda experiência? Talvez possamos afirmar que sim, o que evidenciaria mais uma estratégia no sentido de jogar com os tempos na narrativa. "Pinto aquele da 12a lâmina do Tarô: o homem enforcado - o sacrifício, voluntário, gerador de forças. Esse, é o que me representa." (p.188, grifos nossos). A quem o enforcado representa? A ele ou a Gaitán? Ou a ambos, confundidos? Há um possível jogo aqui, relacionado ao vocábulo representar. O enforcado como representação do protagonista, ou como representação de Gaitán, com o qual o narrador se identifica e se sente 'representado' por ele, explicitando uma relação de empatia em relação ao povo colombiano? Nesse caso, mais uma voz se faria presente, emergindo do discurso direto/indireto do narrador, com a deste mesclada. Ou milhares de vozes, se considerarmos como jogo o uso que o autor faz da palavra representar.

"Páramo" foi escrito em 1948 e publicado em 1969, como já dissemos, pouco mais de um ano após a morte do autor. Em quase vinte anos, o que corresponde a todo o período produtivo do escritor Rosa, houve tempo para que este trabalhasse, reescrevesse e atualizasse o conto, e que este fosse se tornando o acúmulo de experiências não contadas, ou verbalizadas, e de diálogos muitos. Ou seja, tempo para que o autor conversasse com a obra e que diálogos outros fossem estabelecidos entre ele próprio e sua obra, além destes com outros autores e obras. Nada sabemos a respeito desse trabalho de duas décadas nas quais o autor se debruçou e retomou a escritura do conto. Impossível traçar a gênese da obra. No entanto, fica claro na leitura de "Páramo" que há certa heterogeneidade em relação a alguns aspectos. Alguns deles, mais objetivos, são identificáveis, sobretudo aqueles relacionados à linguagem.

Há um importante componente intertextual na obra, observável em diversos níveis. $\mathrm{E}$ não somos os primeiros a chamar a atenção para esse aspecto, embora, como é natural que seja em se tratando da leitura que tem em vista o diálogo entre textos, outras relações sejam explicitadas, considerando-se a biblioteca que constitui cada leitor ${ }^{2}$, sobrepondo novas camadas ao texto. "Estas camadas novas do texto, dispostas pela prática intertextual, formam com frequência o lugar onde se inscreve, às vezes, abstratamente, a literatura como tecido contínuo e como memória coletiva." (SAMOYAULT, 2008, pp. 89-90)

Portanto, o que podemos dizer é que algumas dessas relações são percebidas à superfície do texto, a partir da citação. Podemos localizar facilmente, por exemplo, um verso do poema "Máquina do mundo", de Carlos Drummond de Andrade (1949), citado, inclusive,

\footnotetext{
${ }^{2}$ Não nos dedicaremos a explicitar todas as relações que identificamos, ou a aprofundá-las, apenas apontaremos algumas delas, posto que este não é o foco principal de nosso estudo, e porque essa investigação ultrapassaria os limites deste artigo.
} 
entre aspas: "Ali, em antros absconsos, na dureza da pedra, no peso do orgulho da terra, estarão situados os infernos - 'no sono rancoroso dos minérios'”33 (ROSA, 1969, p.180). Já Betina Cunha (2014), ao tratar do conto de Rosa, busca a origem de uma notação intertextual, que ela sugere recuperada de uma canção $(p .185)^{4}$, no diálogo que seria do narrador protagonista com uma personagem desconhecida, sem voz narrativa, identificada como sua amada, em outro tempo, passado. Quanto ao "tempo t", um passado que é futuro da imagem evocada, este permanece um mistério.

Pois quem? Pois quando? Sei que, a implacável sorte, separou-nos, uma vez, dobrei o cunhal daquela Casa, ela estava ao portão grande. Enrolo-me na capa. Minha alma soluçava, esperava-me o inferno; e eu disse:

- Oh, Doña Clara, dádme vuestro adiós... [...] Aquilo ia suceder mais tarde - no tempo t. [...] O mistério separou-nos. Por quanto tempo? E - existe mesmo o tempo?[...] Esperava-me ao portal. [...] (p.192)

Em relação aos vínculos que Rosa estabelece com Francisco de Goya e Arnold Böcklin, preferimos falar em relações de intermidialidade ${ }^{5}$. Tratam-se de empréstimos 'referenciados', estão explícitos. Com Goya, o diálogo se dá a partir da série de gravuras denominada Los caprichos, do pintor espanhol, que Rosa aproxima da imagem que constrói do momento do cortejo fúnebre em "Páramo": "os homens com os sombreros de jipijapa [...] as mulheres vestidas com trajes de lanilha preta": "Sim, meu coração saudou-os. Passavam. Eram como num capricho de Goya" (p. 194). Rosa reatualiza a obra do pintor espanhol, o qual por sua vez, retoma o escritor Francisco de Quevedo (CUNHA, 2014, p.188). Ambas são apresentadas por seus autores como sonhos. Quanto à relação com Böcklin, esta se dá com duas obras do pintor alemão: Vita somnium breve, de 1888, e $A$ ilha dos mortos, 1880. Esta última, um quadro para sonhar, segundo o artista: "Aqui têm, como desejaram, um quadro para sonhar. Ele terá de parecer tão silencioso que nos assustamos se alguém bater à porta." ${ }^{6}$. A imagem que constrói Rosa a partir da linguagem é a exata representação da obra pictural:

O lugar aonde eu viera esconder-me, meu transfúgio, era um ponto fechado entre lápides e ciprestes, quase um ninho, só o exigido espaço, folhagem e pedra

\footnotetext{
${ }^{3}$ [...] no sono rancoroso dos minérios/dá volta ao mundo e torna a se engolfar/na estranha ordem geométrica de tudo/e o absurdo original e seus enigmas/suas verdades altas/ mais que tantos monumentos erguidos à verdade/e a memória dos deuses e o solene/ sentimento de morte, que floresce/no caule da existência mais gloriosa/tudo se apresentou nesse relance/e me chamou para seu reino augusto/afinal submetido à vista humana [...]. (Carlos Drummond de Andrade, In: $A$ máquina do mundo, 1949)

4 "Hear how/a Lady of Spain/did love/an Englishman ..." Segundo Betina Cunha (2014), Esse versos fazem parte da balada "The Spanish Lady's Love" cujo texto, tal como se tem notícias, foi impresso e vendido em Bow-Church-Yard, Londres em algum momento do período entre 1736 e 1763 como "O amor da senhora espanhola a um marinheiro Inglês" Sendo, no entanto uma atualização de antigas canções.

${ }^{5}$ Segundo o ponto-de-vista de Irina Rajewsky.

${ }^{6}$ https://virusdaarte.net/arnold-blocklin-a-ilha-dos-mortos/
} 
mausoléia, em luz oblíqua, em suma paz. Tudo ali perdera o sentido externo e humano [...]. Nenhuma voz, nenhum som. Sim eu me recolhera a um asilo em sagrado [...]. (p.196)

No entanto, as relações mais profundas que identificamos em "Páramo", ocorrem a partir do diálogo do autor com escritores, dentre os quais, ele mesmo, mais exatamente com sua obra futura, tendo em vista a data atribuída à escritura do conto. Além disso, é evidente o diálogo com Juan Rulfo e também com Jorge Luis Borges. Com Borges, por exemplo, Rosa conversa a partir de questões relativas ao tempo na narrativa: a manipulação do tempo, e a morte. Em um único trecho, por exemplo, podemos perceber claramente esses vínculos, em especial com os contos "O jardim das veredas que se bifurcam" e "As ruínas circulares", por exemplo:

\begin{abstract}
Ah, penso que os mortos, todos êles, morrem porque quiseram morrer [...]. Mas, o Homem com a presença de cadáver ignora isso [...] Algo nêle quer passar-se para mim; como poderei defender-me? [...] Sei: êle, em alguma vida anterior, foi o meu assassino, assim ligou-se a mim. E, porcerto, aspira, para nós ambos, a uma outra morte, que sempre há mais outra: mais funda, mais espêssa, mais calcada, mais embebida de espaço e tempo. (pp.184-185)
\end{abstract}

No que diz respeito às relações com a obra de Rulfo, estas se dão com a totalidade da obra, o que não impede que possamos distinguir referências mais específicas, como a que se verifica entre "Páramo" e Pedro Páramo, de 1955: Bogotá como uma espécie de Comala.

E de que poderiam aliviar-me, momento que fosse, qualquer um de entre os milhares de pessoas desta cidade [...], Passo por êles, falo-lhes, ouço-os, e nem uma fímbria de nossas almas se roça; tenta-me crer que nem tenham alma; ou a não terei eu? Ou será de outra espécie? Estarão ainda mais mortos que eu mesmo, ou é a minha morte que é mais profunda? (p.183)

Também nos contos de El llano em llamas, naturalmente, encontramos referências. Podemos elencar uma série de exemplos desses vínculos, sobretudo selecionados dos contos de Rulfo que são objeto de nossa análise neste trabalho: "El hombre" e "Luvina". Nesse sentido, destacamos neste momento apenas um, o recurso às subidas e descidas que parecem sempre configurar entradas e saídas de um tempo, presente também em Borges e no grande sertão: o alto e o abaixo como lugares fora do tempo, espaço da experiência limite e da possibilidade de transcendência.

Comenzó a perder el ánimo cuando las horas se alargaron y detrás de un horizonte estaba otro y el cerro por donde subía no terminaba. (El hombre, p.22)

El hombre bajó buscando el río, abriendo una nueva brecha entre el monte. (EI hombre, p.23)

De los cerros altos del sur, el de Luvina es el más alto y el más pedregoso. [...] Y la tierra es empinada. Se desgaja por todos lados en barrancas hondas, de un fondo 
que se pierde de tan lejano. Dicen los de Luvina que de aquellas barrancas suben los sueños [...]. (Luvina, p.60)

Já no que se refere à sua própria obra, podemos dizer que Rosa conversa diretamente com Grande sertão: veredas, de 1956, considerando-se não apenas a linguagem: "A mulher ripostou, primeiro, rixatriz, imediatamente. Daí, encolheu-se, toda tremia. Ela cheirava os volumes da afronta, mastigava-a. [...] tinha em si a energia dos sêres perversos, irremissiva. Clamava, vociferoz [...] ela era a boca de um canal por onde mais ódio se introduzia no mundo." (ROSA, 1969, p.188), mas também as histórias exemplares que têm por tema o mal puro, sem explicação, por exemplo, como no trecho que destacamos acima, e no que reproduzimos abaixo, o qual guarda semelhança com a história de Maria Mutema, que encontramos também em Grande sertão: veredas (ROSA, 1970, pp.170-174), caso contado pelo narrador Riobaldo a seu interlocutor.

Com outra espécie de ódio, que não o do orgulho, mas o da inveja, contam que, em outro país, mas também nas alturas cinéreas da Cordilheira, viveu, longos anos, um mendigo estranho, o qual nunca deixava de carregar consigo um bastão e uma caveira. Tomavam-no por um penitente. Porém, quando morreu, encontraram dentro da caveira um papel, com sua confissão: ele matara outro homem, cuja era a dita caveira, matara-o a pauladas, com o bastão; e carregava os dois objetos, a fim de manter sempre vivo aquele ódio - que era o que lhe dava forças, para viver. (ROSA, 1969, p.187)

O mal em seu sentido mais puro. O diabo na rua no meio do redemunho, o indizível: Bogotazo, experiência que até a posse do autor na Academia brasileira de Letras não foi verbalizada. Até então, Rosa afirmava que não havia presenciado os eventos de abril de 1948, que havia relido Proust (grifo nosso) naqueles dias ${ }^{7}$. "Páramo" parece confirmar que sim, ele presenciou, e é prova mais contundente, pensamos, que a informação no discurso de posse, posto que neste ela se apresenta bastante ambígua. Talvez esse seja um dos motivos pelos quais não tenha publicado o conto, o que nos leva ao grande mistério de "Páramo", o mais evidente, pelo menos: o Livro, que tem a ver com a suposta incompletude

\footnotetext{
7 "Segundo Antonio Callado, que também estava em Bogotá como membro da Delegação Brasileira, Rosa "desapareceu" durante o levante: "Quando ele reapareceu eu disse: 'Puxa, Rosa! Onde é que você andou?' E ele me respondeu: 'Estava todo o tempo na residência do embaixador.' A casa ficava no bairro mais chique de Bogotá, era enorme e tinha um parque imenso. 'Mas você não viu o que aconteceu em Bogotá? Puxa, parecia a história de Augusto Matraga, de tanto que mataram gente... Isso aconteceu no meio da rua, o tempo todo.' Foi então que ele me disse: 'Ora, Callado, o que eu tenho que escrever já está tudo aqui na minha cabeça. Não preciso ver coisa alguma. Está tudo na minha cabeça... Já fiz um livro, estou fazendo outros'. - Mas Rosa, olha, eu garanto que você ficaria impressionado! Foi um espetáculo terrível... O que você fez durante todos esses dias?' Ele disse: 'Eu reli o Proust'. Vejam só! Ele havia descoberto Proust, numa edição francesa, na Embaixada Brasileira, num bairro de Bogotá, e simplesmente se sentou para ler Proust. Ignorou a cidade que pegava fogo porque já tinha todas as guerras de que precisava dentro da cabeça."' (Cadernos de literatura brasileira, 2006, pp. 24-25).
} 
do conto.

\begin{abstract}
Para me esquecer, por um momento, daquele Homem, entrei numa casa, comprei um livro, um passar de matérias. Um livro, um só. Suponho seja de poesias. Será $o$ Livro. Não posso ainda lê-lo. Se o lêsse, seria uma traição, seria para mim como se aderisse mais a tudo o que há aqui, como se me esquecesse ainda mais de tudo o que houve, antes, quando eu pensava que fôsse livre e feliz, em minha vida. Mas devo guardá-lo, bem, o Livro é um penhor, um refém. Nêle estou prisioneiro. E se, para me libertar, livrar-me do estado de Job, eu o desse ao Homem frio como um cadáver? Ah, não. Tudo o que fôsse, dar-Ihe qualquer coisa, seria o perigo de contrair com êle novo laço; mesmo o Livro que por enquanto ainda não deve ser lido. O Livro que não posso ler, em puridade de verdade. $E$, de onde vem, que eu tenho de padecer, tão próximo, êste Homem? Por pecados meus, meus. Tudo o que não é graça, é culpa. Sei - há grandes crimes esquecidos, em cada um de nós, mais que milenarmente, em nosso, de cada um, passado sem tempo. (p.185)
\end{abstract}

Que culpa? e Que crime? - nos perguntamos, além de "Que livro?" Há um vínculo entre culpa/crime e o livro, nos parece certo. Cogitamos que estejam relacionados aos eventos do Bogotazo, mais especificamente com a morte de Gaitán. Pensamos que se poderiam buscar relações. Nesse caso, poderíamos levantar a hipótese de que o livro é o próprio livro por ser escrito, que resulta no conto. Ou um futuro livro sobre a experiência que, de certa forma, é Grande sertão: veredas, lembrando quanto tempo o autor manteve "Páramo" consigo. Metaliteratura, que delata também um jogo com os tempos. Culpa ou superstição? Não sabemos, mas o que não nos parece lícito afirmar, considerando o sujeito Rosa e sua obra, é que haja incompletude em "Páramo", no que se refere a seu conteúdo, ou que o autor ainda fosse decidir que livro seria esse. Trata-se de uma opção, há uma intencionalidade no seu gesto de omitir a citação introduzida por aspas e, consequentemente, a identidade do livro do qual quer se livrar e não consegue. A obra carecia de uma revisão final, é verdade, dado que alguns apontamentos a lápis foram identificados, mas essa citação supostamente faltante, não necessariamente seria incluída. Incluída, poderia significar sua morte, o "sério pressentimento" (ROSA, 1969, p. 197).

O Livro: o que eu, talvez por um sério pressentimento, tão fielmente e bem trouxera comigo. [..] Mas, não. O repentino medo me tolheu, em sinistra agouraria. Eu não ia ler, não poderia ler o Livro. Morresse eu ali, na paz traiçoeira, e tudo ficaria incompleto, sem sentido. Não tinha direito a ler aquele Livro; ainda não tinha. [...] Não pelo presente, ou o passado. O que eu temia, era perder o meu futuro: o possível de coisas ainda por vir, no avante viver, o que talvez longe adiante me aguardava. A vida está tôda no futuro. (p.197)

Portanto, se aceitarmos a hipótese de que o livro mencionado é "Páramo" ou o Grande sertão, por exemplo, fica evidente que ele não poderia citar o que ainda não havia sido escrito naqueles 1948. Nesse sentido, discordamos dos organizadores da edição quando afirmam que "há no original um espaço, em branco, para citação, que o Autor não chegou a preencher." (ROSA, 1969, p. 198). A menos que Rosa tivesse dito isso a eles, o que não 
parece ter ocorrido, pois o teriam referenciado, trata-se provavelmente de interpretação pessoal.

Ao deixar o cemitério, que representa a saída desse outro tempo, sobreposto, afirma o protagonista: “... e era então como se deixasse algo de mim, que deveria ser entregue, pago restituído. [...] Pensei, e fiz. [...] Afinal, de lá me vim." (p. 197). Ademais, "a vida toda está no futuro" (p.197). E volta, para tudo, como diz, para a cidade hostil e o mundo: "Voltava, para o que nem sabia se era a vida ou se era a morte. Ao sofrimento, sempre. Até o momento derradeiro, que não além dele, quem sabe?" (p.198)

Vilma Guimarães Rosa, em seu 'não prefácio' a Estas histórias, datado de 14 de novembro de 1968, ao comentar a escolha de José Olympio, editor, para a publicação da obra, afirma: "Escritos de Rosa, no lugar certo. Entre amigos. E eles sabiam da urgência em publicar o livro deixado pronto para o depois." (ROSA, 1969, p.XIX, o grifo é seu). Rosa, eleito para uma vaga na Academia Brasileira de Letras em 1963, adia a posse por um sentimento premonitório, sabemos, pois ele não o escondia. Em julho de 1967, resolve, por fim, não apenas assumir a cadeira como terminar um livro. Anuncia a publicação de Tutaméia terceiras estórias, que estava sendo lançado, e se despede dos leitores do jornal Pulso ${ }^{8}$, do qual era colaborador: "Gravam-me compromissos excessivos e o tempo que me resta preciso de empregá-lo, sem mais adiamento possível na terminação de outro livro. Outro. Mas este, de novelas e contos longos" ${ }^{\prime 9}$. O livro é Estas histórias, que poderia bem ser as Segundas estórias, a obra que, entre as primeiras e as terceiras estórias, nunca apareceu. Benedito Nunes, em entrevista para o documentário Os nomes do Rosa, em 1996, conta que, ao perguntar ao autor acerca das segundas estórias, quando surgem as terceiras, este haveria se mostrado evasivo e enigmático: "Já tinham saído as Primeiras estórias, então, eu perguntei: 'E as segundas? Essas são as terceiras!' E ele disse: 'Ah, isso é um mistério que eu não posso revelar!' E então, ficou no domínio do segredo, do secreto, do oculto..." (Cadernos de literatura brasileira, 2006, p.52). Em 16 de novembro de 1967, Rosa assume a cadeira na Academia brasileira de Letras, citando em seu discurso a experiência do Bogotazo, como já dissemos. Em 19 de novembro, três dias depois, morre. Percebe-se o significado de "Páramo" no conjunto da obra de Rosa.

Os diálogos estabelecidos em "Páramo" permitem que camadas se sobreponham, camadas de tempo e de sentidos, o que faria também com que o tempo, na obra, seja um tempo para muito além do tempo das duas experiências colombianas. O próprio livro que não podia ser lido (ou que não pode terminar de ser escrito), pois é a matéria da totalidade de sua obra, seu embrião e a sua síntese, que a tudo dá origem e se transforma a partir do que gera. Por esse motivo também não poderia ser publicado. Nesse sentido, não é imperfeito, apenas irregular, como a vida. Pode-se desconfiar que o conto estaria acabado

\footnotetext{
${ }^{8}$ Pulso. Jornal médico, publicado pelo laboratório Sidney Ross, editado no Rio de Janeiro, sob a coordenação de Roberto de Souza Coelho, médico, e de Elísio Valverde, jornalista. Distribuído a consultórios médicos e farmácias, era de circulação nacional.

${ }^{9}$ ROSA, João Guimarães. Rôgo e aceno. In: Jornal Pulso. 29 de julho de 1967.
} 
apenas com a morte do autor. Sustentamos que não havia citação a ser colocada no espaço em branco depois das aspas, ou, se havia, ele não a poderia colocar ali, pois fecharia sua obra e consequentemente sua existência, segundo o sentimento que tinha a esse respeito. "Naquele livro, haveria algo de resgatável" (p.), o espaço em branco como o fio do bordado ${ }^{10}$ que, cortado, impossibilitaria o resgate, mantendo-o preso a esse outro tempo, o do indizível, como se aderisse mais a tudo o que há ali (ROSA, 1969, p. 185).

\section{Considerações finais: as vozes de Rosa e Rulfo: diálogo inconcluso}

É quase natural, ao nos referirmos a relações de intertextualidade, que pensemos nos diálogos de um autor 'com os poetas mortos' (ELIOT, 1989), com a tradição. Não é o caso, no que se refere a Rosa e Rulfo que, além de contemporâneos entre si, chegaram a se conhecer e a estabelecer uma interlocução pessoal. Tampouco se poderia falar em filiação a uma tendência de época, dadas as peculiaridades de sua literatura: a afinidade entre eles e sua produção transcende correntes. $O$ intertexto Rosa-Rulfo se efetiva é com a totalidade de sua obra, concepção de escritura, estratégias narrativas, linguagem, espaço e tempo, contexto, estilo. A literatura se escreve com a lembrança daquilo que é e daquilo que foi, afirma Tiphaine Samoyault (2008, p. 47), mais que intertexto, no que diz respeito aos vínculos entre o brasileiro e o mexicano talvez fosse apropriado falar em dialogismo, pois, muitas vezes, seus textos fazem "ouvir várias vozes sem que nenhum intertexto seja explicitamente localizável" (SAMOYAULT, 2008, p.43). Ainda sobre o diálogo entre os autores, poderíamos dizer que, se este ainda não existia no momento em que Rosa escreve "Páramo", alimentou sua atualização, posto que, em 1948, Rulfo ainda não havia publicado nem El llano em llamas, de 1953, e tampouco Pedro Páramo, de 1955.

Selecionamos os dois contos de Rulfo para contrastá-lo com o de Rosa porque acreditamos que "Páramo" de alguma forma sintetiza "Luvina" e "El hombre". O primeiro como a primeira experiência em Bogotá-Soroche; o segundo como a experiência do Bogotazo, em sua segunda estancia. O espaço é determinante e constitutivo de sujeito em ambos, mas esse espaço é construído pela manipulação ou subversão do tempo, via linguagem/discurso. As formas de trabalho com o tempo em Guimarães são exploradas já em suas primeiras narrativas, ainda de maneira incipiente, por isso estão ainda dissociados, muitas vezes, o tempo do discurso e as questões relativas ao tempo metafisico, por exemplo. E já nesses primeiros momentos de sua produção podemos identificar discurso e estratégias narrativas justificando o insólito. No entanto, diferem os autores naquilo que diz respeito à intensidade de seu uso e até onde vão, no sentido de transcender o tempo ordinário, ou o tempo tal qual podemos apreendê-lo na vida que chamamos real, aquilo que chamamos realidade. Isso se deve talvez ao fato de que não compartilham do mesmo ponto de vista ou o mesmo sentimento em relação ao ser humano, que em Rosa é comoção mais aparente,

\footnotetext{
${ }^{10}$ Marina Colasanti: Além do bastidor. In: Uma ideia toda azul, pp. 16-19.
} 
talvez, em relação a Rulfo, além de uma visão de mundo distinta, considerando o contexto cultural em que se inserem. Se pensarmos na cultura mexicana e na brasileira, por exemplo, sabemos que a relação com a morte, na primeira, é bastante peculiar.

Em Rulfo, o insólito não está no espaço, mas no tempo que configura esse espaço - o outro tempo além do tempo; mas em ambos se trata ainda de jogos com o tempo, a partir da linguagem/discurso. Em Rosa, talvez possamos dizer, grosso modo, que é o espaço que configura o tempo, esse tempo da ancestralidade; e que, em Rulfo, ao contrário, o tempo é que configura o espaço, distendendo ao limite essas noções, 'eliminando' o ponto de vista, dando primazia à ambiguidade da voz. Em ambos, é o discurso que configura o tempo outro da possibilidade no mundo arcaico desses autores. O tempo subvertido é o lugar mítico da experiência, da travessia, passagem. As encruzilhadas e as veredas, o alto e o baixo, terceira margem, páramo. Espectros em um tempo que não se pode medir: Sarapalha; o abandono e as ruínas: Comala.

Podemos falar em um diálogo permanente entre os autores, pois foi sendo construído e trabalhado nas quase duas décadas posteriores, e se estende no tempo após sua morte. "Páramo" foi de fato, essa conversa sempre aberta de Rosa com Rulfo e latinoamerica. Não conhecemos as primeiras versões do conto, talvez nem venhamos a conhecer, tampouco os títulos sob os quais se escondem essas versões: "Confluência"? 0 fato é que Rosa está em "Páramo" mais que em qualquer obra sua. É íntimo. E o diálogo entre os autores segue aberto.

\section{Referências}

BAKHTIN, Mikhail. Marxismo e filosofia da linguagem. Tradução de Michel Lahud e Yara F. Vieira. 9a ed. São Paulo: Hucitec/Anna Blumme, 2002a.

BAKHTIN, Mikhail. Problemas da poética de Dostoiévski. Tradução de Paulo Bezerra. 3ạ ed. Rio de Janeiro: Forense Universitária, 2002b.

BENJAMIN, Walter. O narrador. In: Magia e técnica, arte e política: ensaios sobre literatura e história da cultura. Tradução de Sergio Paulo Rouanet, Prefácio de Jeanne Marie Gagnebin. 7ạ ed. São Paulo: Brasiliense, 1994.

BORGES, Jorge Luis. Ficciones. In: Obra completa. Buenos Aires: Emecé editores, 1974.

CADERNOS de Literatura Brasileira. João Guimarães Rosa. São Paulo: Instituto Moreira Salles. N. 20/21, dez. 2006.

CANDIDO, Antonio. Literatura e subdesenvolvimento. In: A educação pela noite e outros ensaios. São Paulo: Ática, 1987.

CUNHA, Betina Ribeiro Rodrigues. Permanências Impermanentes: Enigmas de "Páramo". Revista Cerrados, v. 23, n. 38, pp. 176-191, 2015. Disponível em: https://www.periodicos.unb.br/index.php/cerrados/article/view/25797 Acesso em: 27/06/2020. 
ELIOT, T.S. Tradição e talento individual. In: Ensaios. Tradução de Ivan Junqueira. São Paulo: Art editora, 1989.

FRIEDMAN, Norman. O ponto de vista na ficção. O desenvolvimento de um conceito crítico. Tradução de Fábio Fonseca de Melo. Revista USP. São Paulo, n.53, pp. 166-182, março-maio de 2002. Disponível em: https://www.revistas.usp.br/revusp/article/view/33195 Acesso em: 23/08/2020.

MANN, Thomas. A montanha Mágica. Tradução: Herbert Caro. São Paulo: Companhia das Letras, 2016.

RICOUER, Paul. Tempo e narrativa. Tomo II. Tradução de Marina Appenzeller. Campinas: Papirus, 1995.

ROSA, João Guimarães. Estas estórias. Rio de Janeiro: José Olympio, 1969.

ROSA, João Guimarães. Grande Sertão: veredas. 7ạ ed. Rio de Janeiro: José Olympio, 1970.

ROSA, João Guimarães. "Páramo". Tradução e nota introdutória de Bairon Oswaldo Veléz Escallón. In: Revista Número. Edición 69, Bogotá, pp. 20-33, Junio-Julio-Agosto, 2011.

ROSA, João Guimarães. Discurso de posse na Academia Brasileira de Letras. 16/11/1967. Disponível em: https://www.academia.org.br/academicos/joao-guimaraes-rosa/discurso-deposse Acesso em: 14/09/2020.

RULFO, Juan. Obra completa. El llano en llamas/Pedro Páramo. Otros textos. Prólogo y cronología Jorge Ruffinelli. 2ª ed. Caracas: Fundação Biblioteca Ayacucho, 1985.

SAMOYAULT, Tiphaine. Intertextualidade. Trad. Sandra Nitrini. São Paulo: Aderaldo e Rothschild, 2008.

VELÉZ ESCALLÓN, Bairon Oswaldo. Guimarães Rosa e o Bogotazo. Revista Landa. Vol. 1 no 2 (2013). Santa Catarina, UFSC, pp.261-281, 2013. Disponível em: https://revistalanda.ufsc.br/PDFs/ed2/BAIRON\%20V\%C3\%89LEZ\%20ESCALL\%C3\%93N.pdf Acesso em: 17/07/2020.

Recebido em: $11 / 10 / 2020$

Aceito em: 06/11/2020 